\title{
PENERAPAN KEBIJAKAN MITIGASI BENCANA (FISIK DAN NONFISIK) DALAM MENGURANGI RISIKO BENCANA DI KABUPATEN BIMA
}

\author{
IMPLEMENTATION OF DISASTER MITIGATION POLICIES (STRUCTURE AND \\ NONSTRUCTURE MITIGATION) IN REDUCING DISASTER RISKS IN BIMA
}

\author{
Haeril $^{1}$, Mas'ud ${ }^{2}$, Taufik Irfadat ${ }^{3}$, Hendra \\ 1,2,3Sekolah Tinggi Ilmu Sosial dan Ilmu Politik (STISIP) Mbojo Bima \\ haeril@stisipbima.ac.id
}

\begin{abstract}
Mitigation is an effort taken to reduce disaster risk by reducing vulnerability and/or increasing capacity in dealing with disasters by building infrastructure, increasing the capacity of government and society. This study used descriptive qualitative method. The location of this research is in the Regional Disaster Management Agency (BPBD) Bima Regency, District regional development planning agencies (Bappeda), and the Environment Office of Bima Regency. Data collection techniques consisted of observation, interviews, and documentation. The results show that the implementation of physical and non-physical mitigation policies as a disaster management effort has not been maximally done to reduce vulnerability and reduce disaster risk in Kabupaten Bima, this is due to the weak capacity of the Regional Government and the community, especially in innovating and building a safety culture. Local governments have also not been maximal in preparing appropriate programs and actions for several priority disasters / high hazard level disasters. In addition, the disaster resilience index of Kabupaten Bima is at level 3, indicating that the Regional Government of Bima regency has implemented several mitigation measures in an effort to reduce disaster risk but with achievements that are still sporadic in nature so that it has not shown good capacity in facing potential disasters that are random time can happen.
\end{abstract}

Keyword: Policy; Mitigation; Risk; Disaster

\begin{abstract}
ABSTRAK
Mitigasi sebagai upaya yang dilakukan untuk mengurangi risiko bencana dengan menurunkan kerentanan dan/atau meningkatkan kemampuan dalam menghadapi bencana dengan membangun infrastruktur, meningkatkan kapasitas pemerintah dan masyarakat. Penelitian ini menggunakan metode deskriptif kualitatif. Lokasi penelitian ini berada di Badan Penanggulangan Bencana Daerah (BPBD) Kabupaten Bima, Bappeda, dan Dinas Lingkungan Hidup Kabupaten Bima. Teknik pengumpulan data terdiri atas observasi,
\end{abstract}


wawancara, dan dokumentasi. Hasil penelitian menunjukkan bahwa penerapan kebijakan mitigasi fisik dan nonfisik sebagai upaya penanggulangan bencana belum maksimal dilakukan untuk menurunkan kerentanan dan mengurangi resiko bencana di Kabupaten Bima, hal tersebut terjadi karena lemahnya kapasitas Pemerintah Daerah dan masyarakat terutama dalam berinovasi dan membangun budaya keselamatan. Pemerintah Daerah juga belum maksimal dalam menyiapkan program dan aksi yang tepat terhadap beberapa bencana prioritas/bencana tingkat bahaya tinggi. Selain itu indeks ketahanan bencana Kabupaten Bima berada pada level 3, menunjukkan bahwa Pemerintah Daerah Kabupaten Bima telah melaksanakan beberapa tindakan mitigasi sebagai upaya mengurangi risiko bencana namun dengan pencapaian-pencapaian yang masih bersifat sporadis sehingga belum menunjukkan kapasitas yang baik dalam menghadapi potensi bencana yang sewaktu-waktu dapat terjadi.

Kata kunci: Kebijakan; Mitigasi; Resiko; Bencana;

\section{PENDAHULUAN}

Pada dasarnya mengurangi risiko bencana ialah dengan mengupayakan aktifitas kewaspadaan dan kesiapsiagaan melalui mitigasi bencana (Faturahman, 2018). Di mana dalam Undang-Undang Nomor 24 Tahun 2007 tentang penaggulangan bencana menjelaskan, bahwa mitigasi merupakan serangkaian upaya untuk mengurangi risiko bencana, baik melalui pembangunan fisik maupun penyadaran, dan peningkatan kemampuan menghadapi ancaman bencana.

Tahap mitigasi dalam upaya penanggulangan bencana adalah cara yang murah dalam mengurangi akibat bahaya-bahaya yang dihadapi masyarakat dibandingkan dengan tindakan lainnya, seperti evakuasi, rehabilitasi dan rekonstruksi (Faturahman, 2018). Minimal terdapat enam langkah yang bisa diupayakan dalam melakukan mitigasi bencana. Pertama, dengan melakukan upaya-upaya perlindungan kepada kehidupan, infrastruktur dan lingkungan. Kedua, adalah dengan meningkatkan pemahaman dan peran serta masyarakat. Ketiga adalah meningkatkan kesiapsiagaan masyarakat terhadap bencana. Keempat, adalah meningkatkan koordinasi dan kapasitas kelembagaan mitigasi Journal of Governance and Local Politics (JGLP) ISSN (online): 2684-9992, Volume: 3, Nomor: 1, Mei 2021 
bencana. Kelima adalah menyusun payung hukum yang efektif dalam upaya mewujudkan upaya-upaya mitigasi bencana. Keenam adalah mendorong keberlanjutan aktivitas ekonomi dan peningkatan kesejahteraan masyarakat melalui kegiatan mitigasi (Jokowinarno, 2011).

Demikian di Kabupaten Bima. Sebagai daerah dengan kondisi geologis, geografis, demografis, dan sosial budaya yang rawan terjadinya bencana, Kabupaten Bima pernah merasakan dampak yang ditimbulkan akibat bencana, dari kerusakan lingkungan, kerugian harta benda, bahkan dampak ekonomi dan psikologis, serta korban jiwa, sehingga memerlukan upaya mitigasi yang sistematis, terpadu, dan terkoordinasi.

Berdasarkan dokumen Rencana Penanggulangan Bencana (RPB) daerah Kabupaten Bima Tahun 2018, bahwa kejadian bencana yang pernah terjadi di Kabupaten Bima yaitu, bencana Banjir dimana tercatat, dalam kurun waktu 10 tahun terakhir, telah terjadi sebanyak 28 kali kejadian di Kabupaten Bima, dengan korban meninggal sebanyak 12 orang, sebanyak 52 orang luka-luka, dan lebih dari 1.000 orang mengungsi. Didapatkan total luasan wilayah yang terdampak bahaya banjir seluas 38,74\% (430.172 Ha) dari luas wilayah Kabupaten Bima, sehingga tingkat bahaya dan risiko yang ditimbulkan banjir pada level sedang berdasarkan Indeks HFA (Hyogo Framework For Action).

Untuk kasus kekeringan, dimana pada tahun 2020 Pemerintah Kabupaten Bima mengeluarkan status siaga darurat kekeringan. Penetapan status ini berdasarkan Surat Keputusan (SK) Bupati Bima, tentang status keadaan siaga darurat penanganan kekeringan dengan Nomor : 188.45/435/06.23 Tahun 2020. Kecamatan yang mengalami kekeringan yaitu Kecamatan Soromandi, Donggo, Bolo, Woha, Madapangga, Palibelo, belo dan Parado. Adapun Desa-desa yang mengalami kekeringan dengan kondisi kritis tiap tahun seperti Kalampa, Samili, dan Waduwani Kecamatan Woha. Kemudian Bre dan Belo Kecamatan Palibelo. Kemudian Desa Rada dan Sanolo Kecamatan 
Bolo, Desa Bajo dan Kananta Kecamatan Soromandi. Didapatkan total luasan wilayah yang terdampak bahaya seluas 99,88\% (430.172 Ha) dari luas wilayah Kabupaten Bima. Kasus kekeringan di Kabupaten Bima berada pada indeks bahaya yang sangat Tinggi.

Kasus kebakaran hutan dan lahan didapatkan total luasan wilayah yang terdampak bahaya seluas 98,55\% (430.172 Ha) dari luas wilayah Kabupaten Bima. Dengan demikian tingkat bahaya kebakaran ini adalah Tinggi. Selain itu bencana kebakaran pemukiman warga juga sering terjadi dari kurun waktu 2019 hingga tahun 2020, tercatat sebanyak 12 kasus kebakaran yang menyebabkan ratusan rumah hangus di 6 Kecamatan yaitu Belo, Woha, Sape, Lambu, Langgudu, dan Parado dengan kerugian ditaksir mencapai Puluhan Miliar Rupiah. Bencana kebakaran menjadi catatan buruk bagi Pemerintah Daerah Kabupaten Bima, respon yang lamban dan keberadaan mobil Damkar yang masih kurang menjadi pemicu terjadinya peningkatan kasus dan kerugian yang terjadi akibat kebakaran. Kabupaten Bima saat ini baru memiliki 10 unit transportasi Pemadam Kebakaran tersebut, yang tentunya belum bisa didistribusikan ke 18 Kecamatan yang ada di Kabupaten Bima. Bahkan kemcamatan Sanggar, Tambora, Parado, dan Belo belum tersedia sama sekali. Kebijakan yang diterapkan saat ini ialah 1 Damkar menghandle dua sampai tiga Kecamatan, tentu ini belum representatif untuk menghandle kebakaran di berbagai wilayah di Kabupaten Bima yang sangat luas.

Menurut Sopiawati (2019) wilayah Kabupaten Bima sebagian besar (70\%) merupakan daerah pegunungan bertekstur dataran tinggi sehingga rawan longsor. Bahaya yang ditimbulkan Tanah longsor juga dengan kategori tinggi, dimana total luasan wilayah yang terdampak bahaya seluas $61,15 \%$ (430.172 Ha) dari luas wilayah Kabupaten Bima.

Bencana di Kabupaten Bima dominasi oleh gempa bumi, gelombang pasang, banjir rob dan abrasi, cuaca ekstrem, gunung api, epidemi dan wabah Journal of Governance and Local Politics (JGLP) ISSN (online): 2684-9992, Volume: 3, Nomor: 1, Mei 2021 
penyakit (Faizah \& Buchori, 2018). Dimana ancaman bencana Gelombang ekstrim, banjir rob, gempa Bumi dan letusan gunung serta epidemi dan penyakit berdasarkan hasil pengkajian risiko bencana BPBD Kabupaten Bima berada pada level sedang. Untuk kasus epidemi dan penyakit, berdasarkan data Satuan Tugas (Satgas) covid-19 Kabupaten Bima, dimana data Covid-19 sampai dengan tanggal 24 Sepetember 2020, tercatat 40 orang dinyatakan sembuh, 13 orang masih Isolasi, dan 3 orang meninggal dunia di Kabupaten Bima.

Berdasarkan data dokumen Rencana Penanggulangan Bencana Daerah Kabupaten Bima tahun 2018, dimana Indeks ketahanan bencana Kabupaten Bima masih berada pada skala/level 3 dari 5 skala berdasarkan indikator Hyogo Frameworks for Actions (HFA). Selain itu, data tingkat kesiapsiagaan dan kapasitas Daerah Kabupaten Bima dalam menghadapi berbagai jenis bencana juga berada pada level rendah dan sangat berisiko. Untuk itu, agar tidak menimbulkan dampak negatif terhadap kerugian ekonomi, sosial, psikologis, dan ekologis yang lebih besar, maka diperlukan upaya mitigasi bencana dengan dengan komitmen tinggi secara kelembagaan sebagai langkah preventif.

Menurut Faturahman (2017) penanggulangan bencana selama ini hanya bertumpu pada masalah saat bencana dan beberapa penyebabnya. Namun kegiatan mitigasi sebagai upaya antisipasi dan upaya untuk memperkirakan konsekuensi potensial bahaya tertentu belum maksimal dilakukan. Urgensi dari penelitian ini adalah untuk menjawab sejauh mana penerapan mitigasi fisik dan non-fisik sebagai upaya untuk mengurangi risiko bencana dengan menurunkan kerentanan dan mampu meningkatkan kemampuan menghadapi bencana dengan upaya membangun infrastruktur dan meningkatkan kapasitas Pemerintah dan Masyarakat dalam menghadapi bencana di Kabupaten Bima. 


\section{METODE PENELITIAN}

Penelitian ini menggunakan metode deskriptif kualitatif. Dalam pendekatan ini peneliti akan meneliti individu atau unit sosial tertentu secara lebih mendalam dengan berusaha untuk menemukan semua variabel penting yang terkait dengan diri subyek yang diteliti. Lokasi penelitian ini berada di Badan Penanggulangan Bencana Daerah (BPBD) Kabupaten Bima, Bappeda, dan Dinas Lingkungan Hidup Kabupaten Bima, lokasi tersebut sangat strategis dalam melihat studi kasus dan permasalahan yang terjadi.

Subyek penelitian ini dipilih melalui teknik nonprobability sampling, dengan menggunakan teknik purposive sampling atau teknik penentuan sampel dengan mempertimbangkan aspek tertentu. Teknik pengumpulan data terdiri atas observasi (observation), wawancara (interview), dan dokumentasi (documentation).

Setelah data selesai dikumpulkan dengan lengkap dari lapangan, tahap berikutnya yang harus lakukan adalah tahap analisa data. Dalam penelitian ini menggunakan teknik analisa data model interaktif menurut Miles dan Huberman yang terdiri dari dari tiga hal utama, yaitu; reduksi data, penyajian data, dan penarikan kesimpulan/verifikasi.

\section{HASIL DAN DISKUSI}

Sebagai langkah untuk mengurangi risiko bencana dengan menurunkan kerentanan dan/atau meningkatkan kemampuan menghadapi bencana. Pemerintah Daerah Kabupaten Bima melalui Peraturan Daerah Nomor 1 Tahun 2014 tentang penanggulangan bencana pada pasal 5 dimana terdapat beberapa hal yang menjadi tanggung jawab Pemerintah Daerah dalam upaya penyelenggaraan mitigasi bencana antaralain;

1. Pemaduan penanggulangan bencana dalam perencanaan pembangunan Daerah dengan cara mencantumkan unsur-unsur rencana penanggulangan 
bencana dan pengurangan risiko bencana dalam Rencana Pembangunan Jangka Panjang Daerah, Rencana Pembangunan Jangka Menengah Daerah, dan Rencana Kerja Pemerintah Daerah;

2. Sebagai upaya memberikan perlindungan masyarakat dari ancaman dan dampak bencana;

3. Pengalokasian dana penanggulangan bencana daerah dalam anggaran pendapatan dan belanja daerah yang memadai pada setiap tahap prabencana, tanggap darurat, dan pascabencana.

Dalam data Rencana Penanggulangan Bencana (RPB) daerah Kabupaten Bima Tahun 2018 bahwa upaya mitigasi dibedakan menjadi dua yaitu, pertama adalah mitigasi fisik (Structure Mitigation) sebagai upaya yang dilakukan untuk mengurangi risiko bencana dengan menurunkan kerentanan dan/atau meningkatkan kemampuan menghadapi bencana dengan membangun infrastruktur. Kedua, mitigasi nonfisik (Nonstructure Mitigation) adalah upaya yang dilakukan untuk mengurangi risiko bencana dengan menurunkan kerentanan dan/ atau meningkatkan kemampuan menghadapi bencana dengan meningkatkan kapasitas pemerintah dan masyarakat dalam menghadapi bencana.

\section{Mitigasi Fisik (Structure Mitigation)}

Pada dasarnya kebijakan penanggulangan bencana merupakan suatu kebijakan yang diambil berdasarkan prinsip-prinsip dasar penanggulangan bencana di Kabupaten Bima. Prinsip ini harus berpedoman pada Rencana Pembangunan Jangka Menengah Daerah (RPJMD) Kabupaten Bima dan selaras dengan prinsip penanggulangan bencana provinsi dan Nasional yang mengupayakan prinsip cepat dan tepat, prioritas, koordinasi dan keterpaduan, transparansi dan akuntabilitas, Kemitraan dan Pemberdayaan. 
Aktifitas Penyelenggaraan Penanggulangan Bencana di Kabupaten Bima semua tertuang dalam dokumen Rencana Penanggulangan Bencana (RPB), yang merupakan dokumen induk penyelenggaraan penanggulangan bencana yang melingkupi seluruh fase penanggulangan bencana di Kabupaten Bima. Dokumen RPB dapat dikatagorikan sebagai "master plan" atau rencana induk penyelenggaraan penanggulangan bencana untuk periode 5 tahun. Sebagai rencana daerah, RPB harus merangkum perspektif penyelenggaraan penanggulangan bencana dari seluruh instansi Pemerintahan Daerah yang terlibat.

\section{Gambar 1. Posisi Rencana Penanggulangan Bencana dalam Perencanaan}

\section{Pembangunan}

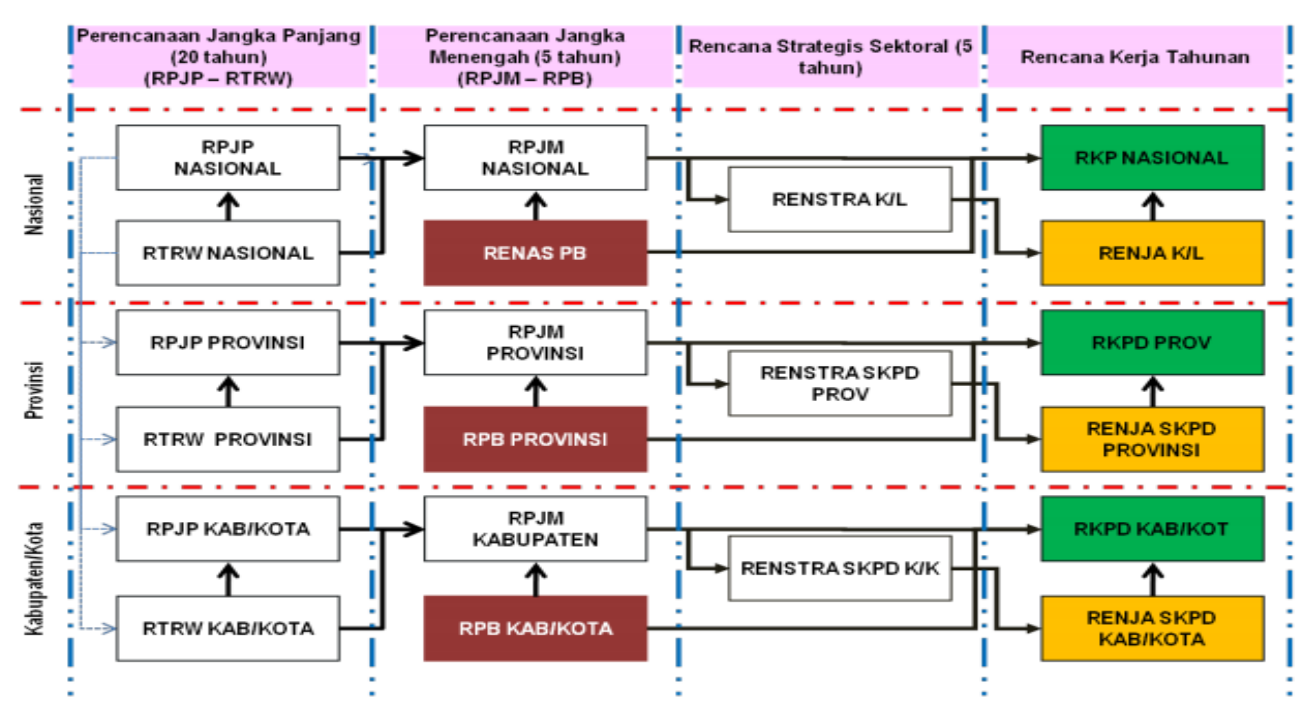

Sumber : Dokumen RPB Kab. Bima tahun 2018

Salah satu tujuan mitigasi bencana adalah untuk Pengurangan Risiko Bencana (Disaster Risk Reduction). Pengurangan Risiko Bencana adalah segala tindakan yang dilakukan untuk mengurangi kerentanan dan meningkatkan kapasitas terhadap jenis bahaya tertentu atau mengurangi potensi jenis bahaya tertentu. 
Berdasarkan data hasil analisis peta resiko bencana dan bahaya di Kabupaten Bima, dapat dijelaskan bahwa jenis bahaya yang ada di Kabupaten Bima memiliki tingkat yang bervariasi. Tingkatan ini dapat dilihat dari luasan daerah dan pengelompokan nilai indeks dari potensi bahaya tersebut. Seperti halnya Kekeringan, Kebakaran hutan dan lahan, Tsunami, Tanah Longsor yang memiliki luas wilayah terdampak dengan kelas tinggi. Sedangkan untuk jenis bahaya Banjir, Cuaca Ekstrim, Epidemi dan wabah penyakit, Gempabumi, Gelombang ekstrim abrasi Letusan dan Gunungapi memiliki luasan bahaya yang bervariasi untuk beberapa kecamatan.

Penentuan tingkat resiko dan bahaya disesuaikan dengan jenis potensi bahaya yang terjadi di suatu daerah. Dengan data tingkat bahaya diperoleh dari hasil pengkajian bahaya rendah, sedang, atau tinggi yang memiliki luas bahaya yang paling besar. Skala indeks bahaya dibagi kedalam tiga kategori yaitu rendah (nilai indeks $0-0,33$ ), sedang (nilai indeks 0,34-0,66) dan tinggi (nilai indeks $(0,67-1)$. Berikut adalah tingkat bahaya yang berpotensi terjadi di Kabupaten Bima;

Tabel 1. Tingkat bahaya yang berpotensi terjadi di Kabupaten Bima

\begin{tabular}{|c|l|r|l|}
\hline No. & \multicolumn{1}{|c|}{ Jenis Bahaya } & Indeks Bahaya & Tingkat Bahaya \\
\hline 1 & Banjir & 0,663 & Sedang \\
\hline 2 & Cuaca Ekstrim & 0,6326 & Sedang \\
\hline 3 & Epidemi dan Wabah Penyakit & 0,333 & Rendah \\
\hline 4 & Gempabumi & 0,6025 & Sedang \\
\hline 5 & Gelombang Ekstrim dan Abrasi & 0,5522 & Sedang \\
\hline 6 & Kekeringan & 0,8919 & Tinggi \\
\hline 7 & Kebakaran Hutan dan Lahan & 0,7938 & Tinggi \\
\hline 8 & Letusan Gunungapi & 0,333 & Rendah \\
\hline 9 & Tanah Longsor & 0,8175 & Tinggi \\
\hline 10 & Tsunami & 0,889 & Tinggi \\
\hline
\end{tabular}

Sumber : Dokumen RPB Kab. Bima tahun 2018-2022 
Adapun beberapa upaya adaptasi mitigasi fisik yang dilakukan Pemerintah Daerah Kabupaten Bima berdasarkan potensi bencana dan tingkat bahaya yang timbulkannya. Dimana hasil temuan menunjukkan bahwa Pemerintah Daerah Kabupaten Bima berupaya menerapkan mitigasi fisik dalam upaya penanganan darurat Kekeringan di Kabupaten Bima, karena berdasarkan hasil identifikasi dari BMKG, bahwa bulan juni sampai Novermber tahun 2020 curah hujan tidak ada sehingga menimbulkan kekeringan. Untuk itu BPBD mengambil langkahdengan upaya penyaluran air bersih sebanyak 20.000 liter perhari pada lokasi yang terdampak kekeringan luar biasa di Kabupaten Bima seperti di Kecamatan Soromandi, Donggo, Bolo, Woho, Madapangga, Palibelo, belo dan Parado.

Namun penyaluran air bersih sebanyak 20.000 Liter perhari tersebut belum mampu memenuhi kebutuhan air bersih bagi seluruh masyarakat yang terdampak, itu pun baru mencakup air minum belum menyeluruh untuk kegiatan lainnya seperti mandi, mencuci maupun memasak. Keterbatasan tersebut diakibatkan oleh minimnya dana operasional dalam penanggulangan bencana kekeringan di Kabupaten Bima.

Untuk itu sebagai solusi jangka panjang Pemerintah mengupayakan pengeboran sumur bor sebagai langkah untuk mengatasi kekeringan. Setiap Desa memang sudah menyiapkan satu sumur bor, namun belum mampu menjadi alternatif solusi karena lokasi dalam satu desa yang sangat jauh, maka yang paling representatif ialah dengan melakukan pengeboran 1 sumur pada 1 RT.

Kemudian melalui Badan Penaggulangan Bencana Daerah (BPBD) Kabupaten Bima, telah mendapatkan hibah seperangkat alat komunikasi berupa 1 monitor mondopad 2.0 ukuran 80 inci. Alat ini digunakan untuk berkoordinasi dalam penangan bencana di daerah ke BNPB. Monitor mondopad senilai Rp 1,6 miliar tersebut, merupakan alat tercepat untuk mengatasi penanganan bencana di Kabupaten Bima. Perangkat ini menggunakan prosesor Intel i7 dan RAM Journal of Governance and Local Politics (JGLP) ISSN (online): 2684-9992, Volume: 3, Nomor: 1, Mei 2021 
sebesar 8 GB, konektivitas Bluetooth 4.0 dan HDMI, serta pilihan-pilihan kamera dengan sambungan USB 3.0 yang bisa digunakan untuk video call ke BNPB dan kantor BPBD di seluruh Indonesia. Sehingga ketika ada bencana, Pusdalop bisa menerima laporan melalui siaran videocall dan radio langsung dari lokasi bencana. Informasi tersebut diverifikasi dan selanjutnya dikirim ke Pusat Data dan Informasi (Pusdatin) BNPB Jakarta.

Selain itu BPBD Kabupaten Bima juga mendapat bantuan 1 unit radio komunikasi dari BNPB RI, yang terhubung langsung ke BNPB dan kantor BPBD di seluruh Indonesia. Secara teknis, perangkat radio ini menjadikan komunikasi radio terkait kebencanaan hanya terpusat di BPBD. Radio amatir tidak lagi mengeluarkan statement sendiri-sendiri berkaitan dengan informasi kebencanaan yang bisa menimbulkan bias informasi dan kepanikan di tengah masyarakat.

Pusdalops (Pusat Pengendalian Operasi) Penanggulangan Bencana di BPBD Kabupaten Bima juga dilengkapi beberapa unit komputer untuk verifikasi dan pengolahan data kebencanaan. Kehadiran perangkat komunikasi canggih ini diharapkan semakin mempercepat akses informasi dan kaji cepat dampak bencana oleh personel BPBD. Disamping memudahkan mitigasi bencana dan semakin cepat mengambil keputusan dalam penanganan bencana. Soal jaringan informasi, BPBD Kabupaten Bima sudah melakukan kolaborasi dengan BMKG sehingga pemantauan iklim dan cuaca bisa diinformasikan langsung dari BPBD.

Selain itu pada tahun 2020, BPBD Kabupaten Bima mendapat bantuan dari BNPB dan BMKG kaitannya dengan alat pendeteksi longsor yang telah terpasang di Kecamatan Lambitu sebagai kawasan rawan longsor. Dimana alat tersebut berfungsi untuk mengidentifikasi retakan tanah. Selain itu, BPBD juga mendapatkan bantuan alat pendeteksi gempa atau alat pemantau gempa Seismograf. Alat tersebut dipergunakan untuk mendeteksi gempa bumi atau getaran pada permukaan tanah. Ketika gempa terjadi maka akan segera Journal of Governance and Local Politics (JGLP) ISSN (online): 2684-9992, Volume: 3, Nomor: 1, Mei 2021 
dideteksi, maka pena pada seismograf akan bergerak menggambarkan tingkat getaran pada kertas.

Namun, Bencana kebakaran menjadi catatan buruk bagi Pemerintah Daerah Kabupaten Bima, respon yang lamban dan keberadaan Mobil Damkar yang masih kurang menjadi pemicu terjadinya peningkatan kasus dan kerugian yang terjadi akibat kebakaran. Kabupaten Bima saat ini baru memiliki 10 unit transportasi Pemadam Kebakaran tersebut, yang tentunya belum bisa didistribusikan ke 18 Kecamatan yang ada di Kabupaten Bima. Bahkan kemcamatan Sanggar, Tambora, Parado, dan Belo belum tersedia sama sekali. Kebijakan yang diterapkan saat ini ialah 1 Damkar menghadle dua sampai tiga Kecamatan, tentu ini belum representatif untuk menghandle kebakaran di berbagai wilayah di Kabupaten Bima yang sangat luas.

\section{Mitigasi Nonfisik (Nonstructure Mitigation)}

Hasil temuan menunjukkan bahwa pelaksanaan mitigasi (nonfisik) bencana dalam upaya penanggulangan bencana di Kabupaten Bima, Pemerintah Daerah beserta Satuan Kerja Perangkat Daerah telah bekerja secara produktif dan kolaboratif terutama dalam penguatan kerangka hukum penyelenggaraan penanggulangan bencana, upaya peningkatan kapasitas dan akuntabilitas tata kelola penanggulangan bencana, pengarusutamaan Penanggulangan Bencana dalam pembangunan, pemaduserasian mekanisme penyelenggaraan penanggulangan bencana, peningkatan kemitraan multi pihak, serta peningkatan kesiapsiagaan dan penanganan darurat bencana.

Dengan demikian, keberhasilan penyelenggaraan mitigasi (nonfisik) sebagai upaya penanggulangan bencana ini akan sangat mengacu pada kemampuan lembaga Pemerintah Kabupaten Bima sebagai unsur penyelenggara pemerintahan daerah untuk membuat kebijakan dan melaksanakannya secara efektif. Sehingga upaya mitigasi (nonfisik) yang dilakukan oleh Pemerintah Daerah Kabupaten Bima melalui Badan Penanggulangan Bencana Daerah 
(BPBD) adalah dengan melakukan upaya sosialisasi dan publikasi data kajian resiko kebencanaan seperti kajian ancaman, kajian kerentanan, dan kajian kapasitas. Kajian risiko bencana dilakukan sebagai strategi untuk mengurangi risiko bencana di Kabupaten Bima. Pengkajian resiko bencana juga dilakukan untuk menghasilkan peta risiko untuk setiap bencana yang ada pada suatu kawasan di Kabupaten Bima. Kajian dan peta risiko bencana ini harus mampu menjadi dasar yang memadai bagi daerah untuk menyusun kebijakan penanggulangan bencana. Untuk masyarakat hasil pengkajian ini dapat dijadikan dasar yang kuat dalam upaya pengurangan risiko bencana. Dalam pengkajian Resiko Bencana melibatkan BPBD, Bappeda, Dinsosnaker, Kesbangpol, Dishubkominfo, BMKG, BPMPKB, PU, Dinkes, dan Desa rentan bencana. Berikut adalah gambar metode pengkajian resiko bencana;

\section{Gambar 2. Metode Pengkajian Resiko Bencana}

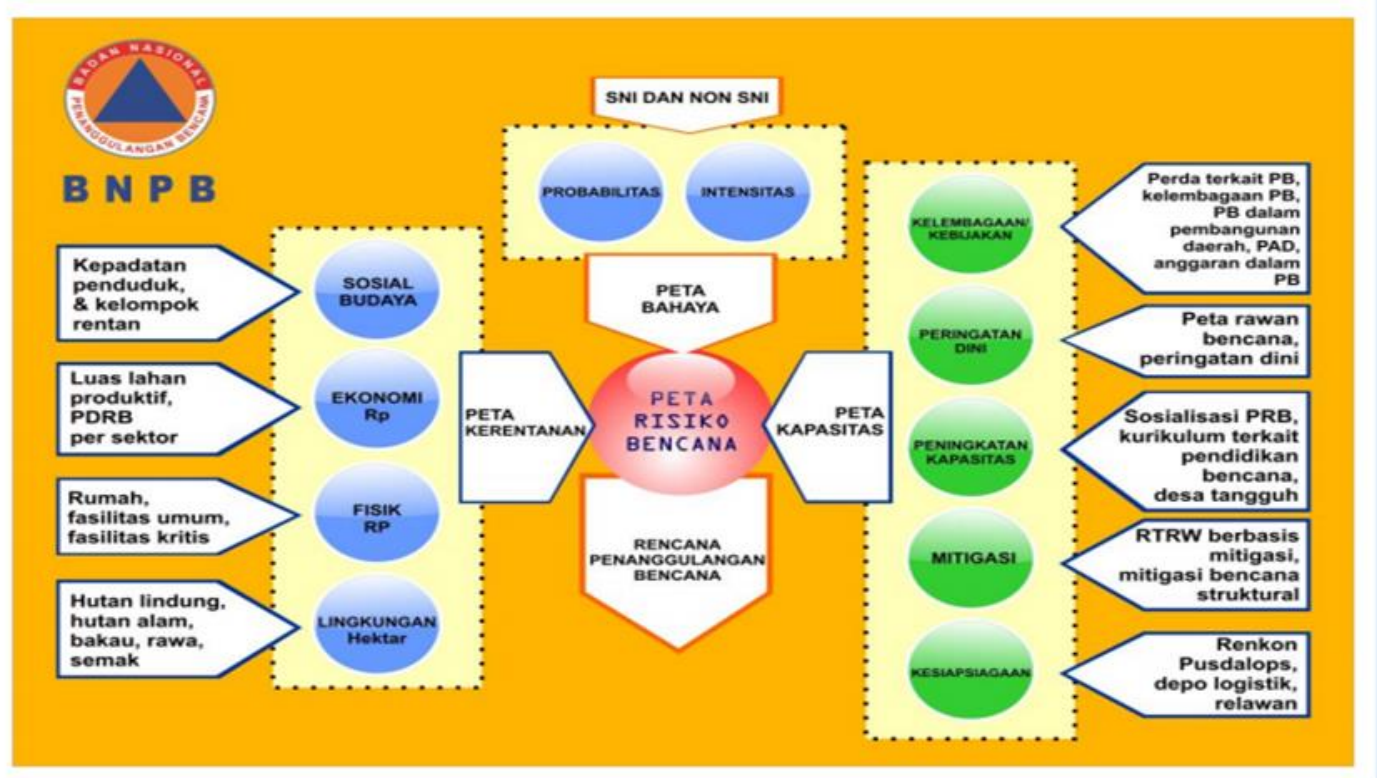

Sumber: Dokumen RPB Kab. Bima tahun 2018-2022

Kemudian, Pemerintah Daerah Kabupaten Bima berupaya memperkuat aturan dan Kapasitas Kelembagaan terutama upaya dan diseminasi aturan dan pedoman Teknis pelaksanaan Rencana Tata Ruang Wilayah melalui PERDA Journal of Governance and Local Politics (JGLP) ISSN (online): 2684-9992, Volume: 3, Nomor: 1, Mei 2021 
Kabupaten Bima Nomor 01 Tahun 2019 tentang Rencana Detail Tataruang (RDTR). Adapun beberapa bentuk aksi yang dilakukan oleh BPBD bersama BAPPEDA, Dishubkominfo, BMKG,BPMPKB, dan Perizinan Umum, yaitu;

1. Dengan memberlakukan zonasi bangunan di daerah berisiko Bencana terutama di wilayah dengan tingkat kemiringan yang dapat memicu bencana longsor.

2. Kemudian dengan mengupayakan pemutakhiran dan implementasi pemberian IMB berbasis pengurangan risiko bencana.

3. Peningkatan Pengawasan dan Pengendalian pemanfaatan tata guna lahan dan IMB bangunan dalam upaya penanggulangan bencana,

4. Penegakan aturan daerah terkait pemukiman,

Kemudian Pemerintah Daerah Kabupaten Bima memalui BPBD yang bertindak sebagai koordinator, fasilitator, motivator, sekaligus pelaksana program-program menerapkan enam strategi penanggulangan bencana sebagai langkah mitigasi nonfisik yaitu;

1. Perkuatan Aturan dan Kapasitas Kelembagaan

Strategi ini merupakan upaya dalam menata ulang peraturan yang mendukung penyelenggaraan penanggulangan bencana. Selain itu juga selaras dengan upaya peningkatan kapasitas kelembagaan yang terkait dengan upaya pengurangan risiko bencana. Upaya perkuatan aturan dan kapasitas kelembagaan dalam pelaksanaannya di Kabupaten Bima difokuskan untuk mencapai penguatan kerangka Hukum penyelenggaraan Penanggulangan Bencana dan peningkatan kapasitas serta akuntabilitas tata kelola penanggulangan bencana.

Harapannya tata kelola yang baik perlu menjadi sebuah komitmen bersama dengan prinsip transparansi dan akuntabilitas serta pengawasan bersama menjadi komponen inti nya. Dalam pengawasan bersama, dibutuhkan suatu mekanisme yang mampu menyediakan data 
yang dapat dimanfaatkan untuk pelaksanaan analisis manfaat-biaya. Analisis manfaat biaya ini dapat memperlihatkan nilai efektivitas program-program yang dijalankan untuk pengurangan risiko bencana dengan harapan dapat meningkatkan akuntabilitas tata kelola yang lebih baik.

2. Perencanaan Penanggulangan Bencana Terpadu

Strategi dalam perencanaan penanggulangan bencana secara lebih terpadu di Kabupaten Bima difokuskan dalam upaya mengintegrasikan RPB kedalam RPJMD. Perencanaan ini ditindaklanjuti kedalam rencana strategis dan rencana kerja tahunan seluruh SKPD. Untuk mencapai sasaran dalam mewujudkan perencanaan penanggulangan bencana terpadu dapat melalui program seperti, pengarusutamaan Penanggulangan Bencana dalam Pembangunan, pemaduserasian mekanisme penyelenggaraan penanggulangan bencana.

3. Pendidikan, Penelitian dan Pelatihan

Dalam strategi ini, diharapkan adanya perubahan jangka panjang yang berfokus pada pergeseran paradigma untuk pengurangan risiko bencana yang lebih efektif. Pola pergeseran paradigma dapat menggunakan pengembangan strategi pendidikan dan penyadaran pada pendidikan formal, nonformal, informal dan bentuk informasi yang mungkin. Pergeseran paradigma ini seharusnya membuat trend baru dan bagian dari gaya hidup modern di masyarakat umum. Sangat penting untuk membangun paradigma ini menjadi sesuatu yang dihargai dan berkembang dengan pola-pola yang mungkin ditiru oleh masyarakat.

Upaya dasar yang dapat dilakukan dengan pemberdayaan hasil riset terapan baik dari perguruan tinggi maupun penelitian yang berkaitan penanggulangan bencana. Salah satunya melalui kajian rasio perbandingan investasi (cost benefit analys) terhadap setiap fase 
penanggulangan bencana. Selain itu dapat dikembangkan juga hasil riset yang dapat diterapkan secara langsung oleh individu dan keluarga seperti pembangunan rumah aman Gempa, sumur resapan dan lainnya. Diharapkan dengan adanya beberapa riset terkait penanggulangan bencana di Kabupaten Bima dapat menurunkan kerentanan daerah terhadap risiko muti bahaya. Selain itu, melalui pendidikan dan pelatihan diharapkan adanya kesadaran dan pola pikir masyarakat dalam melakukan upaya pengurangan risiko bencana.

Penyusunan rencana aksi kesiapsiagaan bencana perlu disusun ditingkat masyarakat secara partisipatif. Dengan Pola pendekatan yang bersifat trend-setter, mengedepankan pembangunan ketangguhan komunitas. Sehingga pengurangan risiko bencana menjadi prioritas dan pengarusutamaan untuk dapat diterapkan sampai ke tingkat desa.

4. Peningkatan Kapasitas dan Partisipasi Masyarakat

Strategi dalam peningkatan kapasitas dan partisipasi masyarakat di Kabupaten Bima difokuskan kepada program pemberdayaan masyarakat dan perkuatan fungsi kemitraan dalam pengurangan risiko bencana melalui optimalisasi pemberdayaan masyarakat untuk penanggulangan bencana. Langkah ini dilakukan untuk menciptakan kemandirian dan keterlibatan aktif masyarakat.

Selain itu adanya peningkatan kemitraan multi pihak dalam penanggulangan bencana. Melalui perkuatan fungsi kemitraan dapat menggalang berbagai sumber daya yang dapat dimanfaatkan untuk pengurangan risiko bencana di luar anggaran APBN dan APBD. Tidak hanya itu, arah kemitraan yang bersifat cair lebih memungkinkan untuk penyelesaian masalah yang bersifat mendesak diluar proses birokrasi. Kemitraan antara pemerintah, dunia usaha, dan masyarakat dikembangkan dalam upaya perlindungan perekonomian. Kemitraan ini 
dapat menggalang kontribusi dukungan partisipatif sektor swasta dan dunia usaha dalam penyelenggaraan penanggulangan bencana.

Kemudian agar tercipta efektivitas penyelenggaraan penanggulangan bencana perlu perkuatan Forum Pengurangan Risiko Bencana (Forum PRB). Melalui forum PRB Kabupaten Bima yang terdiri dari aktor lintas sektoral diharapkan mampu mempercepat kemajuan dalam penyelenggaraan penanggulangan bencana di daerah. Aktor lintas sektoral yang merupakan pemangku kebijakan dan pemangku kepentingan dapat memberikan kontribusi yang cukup besar dalam melaksanaan perencanaan penanggulangan bencana di Kabupaten Bima.

5. Pengurangan Risiko Bencana

Merupakan strategi kolaborasi paling penting yang dilakukan sebelum terjadinya bencana adalah upaya pengurangan risiko. Dimana strategi ini diharapkan dapat mencegah bahaya. Upaya pencegahan bahaya lebih kepada pengurangan tingkat risiko yang akan muncul dengan melakukan pengelolaan pada lokasi sumber bahaya. Dengan adanya perlakuan di sumber bahaya maka diharapkan kejadian bencana dapat dihilangkan.

Kemudian dengan mengurangi kerentanan. Dengan pelaksanaan program ini diharapkan dapat mengurangi tingkat risiko yang akan muncul dengan melakukan mitigasi struktural maupun nonstruktural. Selain itu, peningkatan kapasitas juga diharapkan dapat lebih menyeluruh bukan hanya terfokus satu atau dua jenis bencana saja.

6. Peningkatan Efektivitas Penanganan Darurat Bencana

Upaya peningkatan efektivitas penanganan darurat bencana difokuskan kepada Peningkatan kesiapan menghadapi bencana, dan optimalisasi operasi tanggap darurat dan percepatan pemulihan dini dengan pelibatan BPBD yang didukung oleh Bappeda, Dinsosnaker, 
Kesbangpol, Dishubkominfo, BMKG, BPMPKB, PU, Dinkes, dan Desa-desa yang ada di Kabupaten Bima.

Berikut adalah data Penjabaran strategi spesifik mitigasi setiap jenis bahaya. Strategi spesifik tersebut dikelompokkan kepada 3 (tiga) strategi. Pengelompokkan tersebut untuk lebih menjelaskan hal yang terangkum untuk melihat fokus prioritas, program dan aksi dari masing masing jenis bahaya yang ada di Kabupaten Bima.

a. Banjir

Fokus prioritas, program dan aksi RPB untuk bencana banjir, tercantum pada tabel di bawah ini :

Tabel 2. Pengurangan Resiko Bencana Banjir

\begin{tabular}{|c|c|c|}
\hline FOKUS PRIORITAS & PROGRAM & AKSI \\
\hline \multirow[t]{10}{*}{$\begin{array}{l}\text { Peningkatan Efektivitas } \\
\text { Pencegahan dan } \\
\text { Mitigasi Bencana }\end{array}$} & \multirow{7}{*}{$\begin{array}{l}\text { Optimalisasi pengelolaan } \\
\text { sumber daya serta Penataan } \\
\text { Ruang dan Lahan untuk } \\
\text { upaya pencegahan dan } \\
\text { mitigasi bencana }\end{array}$} & $\begin{array}{l}\text { Menjaga dan memelihara daerah resapan air di } \\
\text { kawasan hutan lindung dan hutan konsevasi daerah } \\
\text { rawan bencana }\end{array}$ \\
\hline & & $\begin{array}{l}\text { Melakukan reboisasi dan pemeliharaan lahan kritis } \\
\text { di kawasan kawasan hutan lindung dan konservasi }\end{array}$ \\
\hline & & Normalisasi dan reklamasi Daerah Aliran Sungai \\
\hline & & Normalisasi sistem pengairan \\
\hline & & $\begin{array}{l}\text { Penerapan aturan tata guna lahan dan ijin } \\
\text { mendirikan bangunan di wilayah rawan bencana } \\
\text { banjir }\end{array}$ \\
\hline & & $\begin{array}{l}\text { Menetapkan dan menerapkan standar pengelolaan } \\
\text { Sumber daya air dan Daerah Aliran Sungai }\end{array}$ \\
\hline & & $\begin{array}{l}\text { Menerapkan peraturan tentang pengamanan dan } \\
\text { pelestarian Sumber daya air }\end{array}$ \\
\hline & \multirow[t]{3}{*}{$\begin{array}{l}\text { Pengelolaan mitigasi } \\
\text { bencana }\end{array}$} & $\begin{array}{l}\text { Mengembangkan inovasi pintu air dengan teknologi } \\
\text { sederhana dan tepat guna }\end{array}$ \\
\hline & & $\begin{array}{l}\text { Menyediakan dukungan, melaksanakan } \\
\text { pembangunan dan perbaikan jaringan utama irigasi } \\
\text { dan bendungan }\end{array}$ \\
\hline & & $\begin{array}{l}\text { Pengamanan dan pelestarian Sumber Daya Air } \\
\text { melalui reklamasi sungai dalam Zona Prioritas } \\
\text { Penanganan Bencana Banjir }\end{array}$ \\
\hline
\end{tabular}

Sumber : Dokumen RPB Kab. Bima tahun 2018-2022 
b.

Cuaca Ekstrim

Tabel 3. Fokus Prioritas, Program, dan Aksi Bencana Cuaca Ekstrim

\begin{tabular}{|c|c|c|}
\hline FOKUS PRIORITAS & PROGRAM & AKSI \\
\hline \multirow{2}{*}{$\begin{array}{l}\text { Peningkatan Efektivitas } \\
\text { Pencegahan dan Mitigasi } \\
\text { Bencana }\end{array}$} & \multirow[t]{2}{*}{$\begin{array}{l}\text { Pengelolaan mitigasi } \\
\text { bencana }\end{array}$} & $\begin{array}{l}\text { Pengembangan kebijakan inovasi teknologi untuk } \\
\text { deteksi dini potensi bencana cuaca ekstrim }\end{array}$ \\
\hline & & $\begin{array}{l}\text { Pembangunan dan perawatan helter perlindungan } \\
\text { serta pengungsian bencana cuaca ekstrim }\end{array}$ \\
\hline \multirow{3}{*}{$\begin{array}{l}\text { Peningkatan } \\
\text { Kesiapsiagaan dan } \\
\text { penanganan darurat } \\
\text { Bencana }\end{array}$} & Pembangunan Kapasitas & $\begin{array}{l}\text { Peningkatan pengetahuan masyarakat tentang } \\
\text { cuaca ekstrim di wilayah yang berpotensi bencana } \\
\text { cuaca ekstrim }\end{array}$ \\
\hline & \multirow[t]{2}{*}{ Kesiapsiagaan Bencana } & $\begin{array}{l}\text { Penyusunan Rencana Penyelamatan Diri saat } \\
\text { terjadi bencana cuaca ekstrim }\end{array}$ \\
\hline & & $\begin{array}{l}\text { Penyelenggaran latihan kesiapsiagaan bencana } \\
\text { cuaca ekstrim }\end{array}$ \\
\hline
\end{tabular}

Sumber :Dokumen RPB Kab. Bima tahun 2018-2022

c. $\quad$ Epidemi dan Wabah Penyakit

Tabel 4. Fokus Prioritas, Program, dan Aksi Bencana Epidemi dan Wabah Penyakit

\begin{tabular}{|l|l|l|}
\hline \multicolumn{1}{|c|}{ FOKUS PRIORITAS } & \multicolumn{1}{|c|}{ PROGRAM } & \multicolumn{1}{c|}{ AKSI } \\
\hline $\begin{array}{l}\text { Peningkatan Efektivitas } \\
\text { Pencegahan dan Mitigasi } \\
\text { Bencana }\end{array}$ & Pengelolaan mitigasi bencana & $\begin{array}{l}\text { Pemberian imunisasi \& vaksinasi berkala } \\
\text { terhadap masyarakat \& lingkungan }\end{array}$ \\
\hline $\begin{array}{l}\text { Peningkatan } \\
\text { Kesiapsiagaan dan } \\
\text { penanganan darurat } \\
\text { Bencana }\end{array}$ & $\begin{array}{l}\text { Sercepatan Pembangunan } \\
\text { dalam Penanganan Darurat }\end{array}$ & $\begin{array}{l}\text { Pengadaan sarana prasarana dan persediaan } \\
\text { obat-obatan penanganan darurat bencana } \\
\text { epidemi dan wabah penyakit }\end{array}$ \\
\cline { 2 - 3 } & $\begin{array}{l}\text { Peningkatan Kapasitas } \\
\text { Penanganan DaruratBencana }\end{array}$ & Kaji cepat bencana \\
\cline { 3 - 3 } & Pencarian, penyelamatan dan evakuasi \\
\cline { 3 - 3 } & & \\
\cline { 3 - 3 } & & Pengisolasian korban bencana \\
\hline
\end{tabular}

Sumber : Dokumen RPB Kab. Bima tahun 2018-2022

Journal of Governance and Local Politics (JGLP)

ISSN (online): 2684-9992, Volume: 3, Nomor: 1, Mei 2021 


\section{d. Kekeringan}

Tabel 5. Fokus Prioritas, Program, dan Aksi Bencana Kekeringan

\begin{tabular}{|c|c|c|}
\hline FOKUS PRIORITAS & PROGRAM & AKSI \\
\hline \multirow[t]{2}{*}{$\begin{array}{l}\text { Peningkatan Efektivitas } \\
\text { Pencegahan dan } \\
\text { Mitigasi Bencana }\end{array}$} & $\begin{array}{l}\text { Optimalisasi pengelolaan sumber } \\
\text { daya serta Penataan Ruang dan } \\
\text { Lahan untuk upaya pencegahan dan } \\
\text { mitigasi bencana }\end{array}$ & $\begin{array}{l}\text { Penerapan peraturan tentang pengamanan } \\
\text { dan pelestarian sumber daya air didaerah } \\
\text { yang beresiko kekeringan }\end{array}$ \\
\hline & Pengelolaan mitigasi bencana & $\begin{array}{l}\text { Melaksanakan pembangunan perbaikan } \\
\text { jaringan utama irigasi. }\end{array}$ \\
\hline \multirow{5}{*}{$\begin{array}{l}\text { Peningkatan } \\
\text { Kesiapsiagaan dan } \\
\text { penanganan darurat } \\
\text { Bencana }\end{array}$} & $\begin{array}{l}\text { Percepatan Pembangunan Sarana } \\
\text { Prasarana dan Logistik dalam } \\
\text { Penanganan Darurat }\end{array}$ & $\begin{array}{l}\text { Pengadaan sarana prasarana penanganan } \\
\text { darurat bencana }\end{array}$ \\
\hline & \multirow{4}{*}{$\begin{array}{l}\text { Peningkatan Kapasitas Penanganan } \\
\text { Darurat Bencana }\end{array}$} & Kaji Cepat Bencana kekeringan \\
\hline & & Pencarian, Penyelamatan dan Evakuasi \\
\hline & & $\begin{array}{l}\text { Pemenuhan kebutuhan dasar pangan, } \\
\text { sandang, hunian sementara, layanan } \\
\text { kesehatan, air bersih dan sanitasi }\end{array}$ \\
\hline & & $\begin{array}{l}\text { Pemulihan darurat fungsi prasarana dan } \\
\text { sarana kritis }\end{array}$ \\
\hline \multirow{2}{*}{$\begin{array}{l}\text { Penyelenggaraan } \\
\text { Pemulihan Dampak } \\
\text { Bencana }\end{array}$} & \multirow[t]{2}{*}{$\begin{array}{l}\text { Rehabilitasi dan Rekonstruksi Bidang } \\
\text { Sosial, Ekonomi dan Budaya }\end{array}$} & $\begin{array}{l}\text { Pengkajian jumlah korban dan kerusakan } \\
\text { perekonomian serta lingkungan }\end{array}$ \\
\hline & & Pemulihan kesehatan dan kondisi psikologis \\
\hline
\end{tabular}

Sumber : Dokumen RPB Kab. Bima tahun 2018-2022 
e. $\quad$ Kebakaran hutan dan Lahan

Tabel 6. Fokus Prioritas, Program, dan Aksi Bencana Kebakaran Hutan dan Lahan

\begin{tabular}{|c|c|c|}
\hline FOKUS PRIORITAS & PROGRAM & AKSI \\
\hline \multirow[t]{2}{*}{$\begin{array}{l}\text { Peningkatan Efektivitas } \\
\text { Pencegahan dan } \\
\text { Mitigasi Bencana }\end{array}$} & \multirow{2}{*}{$\begin{array}{l}\text { Optimalisasi pengelolaan sumber } \\
\text { daya serta Penataan Ruang dan } \\
\text { Lahan untuk upaya pencegahan dan } \\
\text { mitigasi bencana }\end{array}$} & $\begin{array}{l}\text { Menyusun aturan pemanfaatan, } \\
\text { pemeliharaan dan pengendalian kawasan } \\
\text { hutan dan lahan yang berisiko kebakaran }\end{array}$ \\
\hline & & $\begin{array}{l}\text { Penegakkan aturan pengamanan dan } \\
\text { pengendalian kawasan hutan dan lahan } \\
\text { yang berisiko kebakaran }\end{array}$ \\
\hline \multirow{5}{*}{$\begin{array}{l}\text { Peningkatan } \\
\text { Kesiapsiagaan dan } \\
\text { penanganan darurat } \\
\text { Bencana }\end{array}$} & $\begin{array}{l}\text { Percepatan Pembangunan Sarana } \\
\text { Prasarana dan Logistik dalam } \\
\text { Penanganan Darurat }\end{array}$ & $\begin{array}{l}\text { Pengadaan sarana prasarana penanganan } \\
\text { darurat bencana Kebakaran Hutan dan } \\
\text { Lahan }\end{array}$ \\
\hline & \multirow[t]{4}{*}{$\begin{array}{l}\text { Peningkatan Kapasitas Penanganan } \\
\text { Darurat Bencana }\end{array}$} & $\begin{array}{l}\text { Kaji Cepat Bencana kebakaran hutan dan } \\
\text { lahan }\end{array}$ \\
\hline & & Pencarian, Penyelamatan dan Evakuasi \\
\hline & & $\begin{array}{l}\text { Pemenuhan kebutuhan dasar pangan, } \\
\text { sandang, hunian sementara, layanan } \\
\text { kesehatan, air bersih dan sanitasi }\end{array}$ \\
\hline & & $\begin{array}{l}\text { Pemulihan darurat fungsi prasarana dan } \\
\text { sarana kritis }\end{array}$ \\
\hline
\end{tabular}

Sumber : Dokumen RPB Kab. Bima tahun 2018-2022

Namun upaya mitigasi fisik maupun non-fisik di Kabupaten Bima masih belum maksimal dilakukan, rendahnya tingkat ketahanan Daerah Kabupaten Bima terhadap Bencana menjadi bukti bahwa upaya mitigasi selama ini masih mendapati kendala-kendala yang berarti. Berdasarkan Indeks Hyogo Framework For Action (HFA), maka ketahanan daerah Kabupaten Bima berada pada skala/level 3. Berikut adalah tabel hasil kajian tingkat ketahanan Kabupaten Bima berdasarkan hasil survey Indiktor HFA; 
Tabel 7. Indeks Ketahanan Daerah Kabupaten Bima berdasarkan Survey HFA

\begin{tabular}{|c|l|c|c|}
\hline No & \multicolumn{1}{|c|}{ Prioritas } & Total Nilai Prioritas & \multicolumn{1}{|c|}{ Indeks Prioritas } \\
\hline \hline 1 & $\begin{array}{l}\text { Memastikan bahwa pengurangan risiko bencana menjadi } \\
\text { sebuah prioritas nasional dan lokal dengan dasar } \\
\text { kelembagaan yang kuat untuk pelaksanaannya }\end{array}$ & 82,5 & 4 \\
\hline 2 & $\begin{array}{l}\text { Mengidentifikasi, mengkaji dan memantau risiko bencana } \\
\text { dan meningkatkan peringatan dini }\end{array}$ & 62,5 & 3 \\
\hline 3 & $\begin{array}{l}\text { Menggunakan pengetahuan, inovasi dan pendidikan untuk } \\
\text { membangun suatu budaya keselamatan dan ketahanan } \\
\text { disemua tingkat }\end{array}$ & 30 & 3 \\
\hline 4 & $\begin{array}{l}\text { Mengurangi faktor-faktor risiko yang mendasar } \\
\text { Memperkuat kesiapsiagaan terhadap bencana demi } \\
\text { respon yang efektif di semua tingkat }\end{array}$ & 63,75 & 4 \\
\hline TOTAL NILAI PRIORITAS & 83,75 & 3 & 3 \\
\hline INDEKS KETAHANAN DAERAH & 64,5 & 3 \\
\hline
\end{tabular}

Sumber: Dokumen RPB Kab. Bima tahun 2018-2022

Indeks ketahanan bencana Kabupaten Bima berada pada level 3. Hal ini menjelaskan bahwa Pemerintah Daerah Kabupaten Bima telah melaksanakan beberapa tindakan mitigasi sebagai upaya pengurangan risiko bencana dengan pencapaian-pencapaian yang masih bersifat sporadis yang disebabkan belum adanya komitmen kelembagaan dan/atau kebijakan sistematis serta lemahnya daya dukung anggaran dalam penanggulangan bencana, serta pencapaianpencapaian kecil dalam upaya pengurangan risiko bencana dengan melaksanakan beberapa tindakan maju dalam rencana-rencana tertentu namun belum memiliki dampak signifikan.

\section{KESIMPULAN}

Berdasarkan penelitian yang telah dilakukan, maka peneliti dapat menyimpulkan sebagai berikut: 
Bahwa penerapan kebijakan mitigasi fisik dan nonfisik sebagai upaya penanggulangan bencana belum maksimal dilakukan untuk menurunkan kerentanan dan mengurangi resiko bencana di Kabupaten Bima, hal tersebut terjadi karena lemahnya kapasitas Pemerintah Daerah dan masyarakat terutama dalam berinovasi dan membangun budaya keselamatan. Pemerintah Daerah juga belum maksimal dalam menyiapkan program dan aksi yang tepat terhadap beberapa bencana prioritas/ bencana tingkat bahaya tinggi. Selain itu indeks ketahanan bencana Kabupaten Bima berada pada level 3, menunjukkan bahwa Pemerintah Daerah Kabupaten Bima telah melaksanakan beberapa tindakan mitigasi sebagai upaya mengurangi risiko bencana namun dengan pencapaianpencapaian yang masih bersifat sporadis sehingga belum menunjukkan kapasitas yang baik dalam menghadapi potensi bencana yang sewaktu-waktu dapat terjadi.

\section{REFERENSI}

Anggara, S. (2014). Kebijakan Publik. Pustaka setia. Bandung

Asmara, C. J. (2014). Kebijakan Publik Menuju ASEAN Economic Community 2015. Transnasional, 6(1), 1619-1628.

Handoyo, E. (2012). Kebijakan Publik. Widya Karya. Semarang

Black, A. James dan J. Champion, Dean, 2009. Metode \& masalah penelitan Sosial. Bandung. Refika Aditama. Cetakan keempat.

Faizah, N., \& Buchori, I. (2018). Model Pemetaan Risiko Kekeringan Di Kabupaten Bima, Nusa Tenggara Barat(Doctoral Dissertation, Universitas Diponegoro).

Faturahman, B. M. (2018). Konseptualisasi mitigasi bencana melalui perspektif kebijakan publik. Publisia (Jurnal Ilmu Administrasi Publik), 3(2), 121.

Faturahman, B. M. (2017). Reformasi Administrasi Dalam Manajemen Bencana. Mimbar Yustitia, 1(2), 185-201. 
Hilman, D. (2018). Revitalisasi Peraturan Perundangan-Undangan Sebagai Upaya Strategis Penanganan Dampak Perubahan Iklim Di IndonesiA. Jurnal Legislasi Indonesia, 6(1), 146-156.

Idrus, Muhammad. 2009. Metode Penelitian Ilmu Sosial "Pendekatan kualitatif dan Kuantitatif" edisi kedua. Jakarta. Erlangga.

Jokowinarno, D. (2011). Mitigasi bencana tsunami di wilayah pesisir lampung. Rekayasa: Jurnal Ilmiah Fakultas Teknik Universitas Lampung, 15(1), 13-20.

Permana, C. E., Nasution, I. P., \& Gunawijaya, J. (2012). Kearifan lokal tentang mitigasi bencana pada masyarakat Baduy. Hubs-Asia, 10(1).

Rusilowati, A., Binadja, A., \& Mulyani, S. E. S. (2012). Mitigasi Bencana Alam Berbasis Pembelajaran Bervisi Science Environment Technology and Society. Jurnal Pendidikan Fisika Indonesia, 8(1).

Semiawan, C. R. (2010). Metode penelitian kualitatif. Grasindo.

Sugiyono. (2014). Metode penelitian kuantitatif, kualitatif, dan R\&B. Alfabeta. Bandung.

Sopiawati, N. (2019, June). The Role Of Women In The Management Of Flood Disasters In Bima District, Nusa Tenggara Barat. In Iop Conference Series: Earth And Environmental Science (Vol. 271, No. 1, P. 012030). Iop Publishing.

Wandasari, S. L. (2012). Sinkronisasi peraturan perundang-undangan dalam mewujudkan pengurangan risiko bencana. Unnes Law Journal, 1(2)

Undang-Undang nomor 24 Tahun 2007 tentang Penaggulangan Bencana

Dokumen Rencana Penanggulangan Bencana (PRB) Daerah Kabupaten Bima Tahun 2018-2022

Bnpb.go.id

Dokumen Rencana Penanggulangan Bencana Kabupaten Bima Tahun 2018-2022 
PENERAPAN KEBIJAKAN MITIGASI BENCANA (FISIK DAN NONFISIK) DALAM MENGURANGI RISIKO BENCANA DI KABUPATEN BIMA

Https://Www.Suarantb.Com/27-843-Jiwa-Terdampak-Kabupaten-Bima-SiagaDarurat-Kekeringan/ diakses pada tanggal 26 Oktober 2020 